\title{
Non-coding RNAs and ovarian diseases (Review)
}

\author{
DANDAN LI ${ }^{1}$, DUO XU ${ }^{2}$, YINGGANG ZOU ${ }^{1}$, YING XU $^{1}$, LULU FU $^{1}, \mathrm{XIN} \mathrm{XU}^{1}$, \\ YONGZHENG LIU ${ }^{1}$, XUEYING ZHANG ${ }^{1}$, JINGSHUN ZHANG ${ }^{1}$, HAO MING $^{1}$ and LIANWEN ZHENG ${ }^{1}$ \\ ${ }^{1}$ Reproductive Medical Center, Department of Obstetrics and Gynecology, \\ The Second Hospital of Jilin University, Changchun, Jilin 130062; ${ }^{2}$ Department of Breast Oncology, \\ Tumor Hospital of Jilin Province, Changchun, Jilin 130021, P.R. China
}

Received October 27, 2015; Accepted October 26, 2016

DOI: $10.3892 / \mathrm{mmr} .2017 .6176$

\begin{abstract}
Non-coding RNAs (ncRNAs) are a diverse family of untranslated transcripts, which serve important roles in numerous biological processes. ncRNAs are emerging as major mediators of gene expression with crucial regulatory functions. Ovarian diseases have a wide variety of clinical pathological types, which have serious impacts on women's health. In this review, current studies on ncRNAs are summarized with respect to ovarian diseases. Understanding of the role of ncRNAs in ovarian diseases is currently limited; further studies on the molecular mechanisms by which abnormal expression of ncRNAs contributes to ovarian diseases will aid in the identification of ncRNAs as novel diagnostic markers and therapeutic targets for ovarian diseases.
\end{abstract}

\section{Contents}

1. Introduction

2. The discovery of ncRNAs

3. Classification of ncRNAs

4. ncRNAs and ovarian development

5. ncRNAs and ovarian tumorigenesis

6. ncRNAs and other ovarian diseases

7. Significance of ncRNAs in the diagnosis of ovarian diseases

8. Conclusion and perspective

\section{Introduction}

Alterations of mRNAs have been implicated in a variety of human diseases, including cancer, cardiovascular diseases and neurodegenerative disorders, due to the changes in

Correspondence to: Professor Lianwen Zheng, Reproductive Medical Center, Department of Obstetrics and Gynecology, The Second Hospital of Jilin University, 218 Ziqiang Street, Changchun, Jilin 130062, P.R. China

E-mail: zhenglwjlu@sina.com

Key words: non-coding RNA, ovarian tumor, polycystic ovary syndrome, premature ovarian failure, diagnosis protein expression levels (1-4). By contrast, ncRNAs represent a diverse family of ribonucleic acid transcripts that do not have protein-coding potential (5). The ENCODE Project established that the majority of the human transcriptomes are ncRNAs, which are involved in almost all physiological or pathological processes (6-8). With the development of genome-wide sequencing technology, more ncRNAs are being identified and characterized (9).

ncRNAs include microRNA (miRNA), small nucleolar RNA (snoRNA), small interfering RNA (siRNA), PIWI-interacting RNA (piRNA), the heterogeneous group of long non-coding RNA (lncRNA), transcribed ultraconserved region (T-UCR) and numerous other types of ncRNAs (10-13). Previously, dysfunctional miRNA-mediated regulation has been implicated in the pathogenesis of various disorders including cancer and diabetes, oncomiRs including miRNA-21 (miR-21) and miR-221/222 regulate the expression of their targets such as estrogen receptor a to modulate the progression of cancer (14-16). On the other hand, autoimmune diseases such as scleroderma have been associated with autoantibodies to protein components specific to U3 small nucleolar ribonucleoproteins (snoRNPs) $(17,18)$; lncRNAs were closely associated with the differentiation of nerve, muscle and skin (8); and types of ncRNAs including T-UCRs, piRNAs and long intergenic noncoding RNAs (lincRNAs) were associated with human diseases. Overall, the role of ncRNAs in human diseases is gaining interest.

Ovarian diseases have a wide variety of clinical pathological types, including ovarian tumors, polycystic ovary syndrome (PCOS), premature ovarian failure (POF) and other disorders. Previous studies have demonstrated that ncRNAs were differentially expressed in ovarian diseases (19-22). For example, miR-132, miR-320, miR-520c-3p, miR-24 and miR-222 regulated estradiol concentrations, while miR-24, miR-193b and miR-483-5p regulated progesterone concentrations. In addition, miR-132 and miR-320 were expressed at significantly lower levels in the follicular fluid of patients with PCOS than in the healthy controls (20). miR-23a was highly expressed in the plasma of patients with POF and it targeted SMAD5 to regulate apoptosis in human granulosa cells (22). The present review aimed to summarize recent studies that reported the changes of several ncRNAs in ovarian diseases, which may contribute to the pathogenesis of ovarian diseases. 


\section{The discovery of ncRNAs}

In the early 1970s, the non-coding sequences were identified and referred as 'junk DNA' (23). Over the past decade, however, understanding of the non-coding genomes has increased $(24,25)$. The comprehensive understanding of non-coding sequences was initiated in the 1990s, epitomized by the ENCODE consortium, which claimed complete genome sequences of numerous species (6). Subsequent to this, the ENCODE consortium identified that the majority of non-coding genomes may affect cellular and large-scale phenotypes and thus should be considered as having biochemical function. In addition, some representative ncRNAs, such as miRNAs and piRNAs, have been identified.

\section{Classification of ncRNAs}

ncRNAs, a diverse family of transcripts that have no potential of coding protein, include miRNA, snoRNA, siRNA, piRNA, IncRNA, T-UCR and numerous other types of ncRNAs (Table I) (10-13).

miRNAs. miRNAs, the most widely studied class of ncRNAs, act as endogenous 18-24 nucleotide long RNA molecules that recruit RNP complexes to the complementary RNAs (26). miRNAs regulate particular mRNA targets through binding to specific sequences. The outcome of miRNA binding is to inhibit target protein expression. However, the effect is not to silence mRNA expression, rather is a more nuanced effect to decrease protein levels. This can be amplified by binding multiple miRNAs to a single target, or by the targeting of multiple proteins in the same pathway (26). Numerous processes, including proliferation, differentiation, apoptosis and development, have been reported to be regulated by miRNAs $(27,28)$.

piRNA. piRNAs are small RNA molecules 24-32 nucleotides long, which are abundant in the germline across animal species (29). piRNAs are transcribed from intergenic transcripts that are enriched in transcribed transposable elements and other repetitive elements (30-32). Previously, two piRNA-associated mechanisms have been described in Drosophila melanogaster: The cleavage of transposable element transcripts by PIWI proteins (33) and heterochromatin-mediated gene silencing (34).

snoRNA. snoRNAs, 60-300 base pairs (bp) long, were the first identified components of snoRNPs (35). The complexes are responsible for post-transcriptional modifications of ribosomal RNAs (rRNAs) through sequence-specific 2'-O-methylation and pseudouridylation of rRNA $(35,36)$. snoRNAs are responsible for targeting the assembled snoRNPs to facilitate rRNA folding and stability (37).

siRNA. As 20-30 nucleotide long RNA molecules, siRNAs have emerged as critical regulators in the expression and function of eukaryotic genomes (38). Previous studies suggest widespread usage of endo-siRNAs as endogenous regulators of gene expression $(39,40)$. siRNAs protect genome integrity in response to foreign or invasive nucleic acids including viruses, transposons, and transgenes (38). Almost all siRNAs, whether endo-siRNAs or virus siRNAs, silence the same locus from which they are derived (38).

IncRNA. IncRNAs, a heterogeneous group of non-coding transcripts more than 200 nucleotides long, are typically transcribed and frequently spliced and polyadenylated $(41,42)$. lncRNAs account for the majority of the ncRNAs in mammals (43). IncRNAs are predominantly localized in the nucleus and act as signals, scaffolds for protein-protein interactions, molecular decoys and guides to target elements in the genomes or transcriptomes (44). The earliest discovered lncRNAs include H19 (45) and Xist (12).

Other types of ncRNAs. Numerous other classes of ncRNA have been reported, for example endo-siRNA (22 nucleotide-long small RNAs that arise from sense-antisense RNA hybrids, pseudogene transcripts, transposable elements and mRNA exons or introns) (46), T-UCRs (DNA segments that are longer than 200 bp and are completely conserved) (47) and telomeric repeat containing RNAs (maintain the integrity of telomeric heterochromatin by regulating telomerase activity) (48). The biological functions for these ncRNAs remain poorly defined.

\section{4. ncRNAs and ovarian development}

Ovarian growth is a series of complex and coordinated processes, accompanied by significant morphological and functional changes in different follicular cells. Among the small ncRNAs associated with ovarian development, miRNAs are the most widely studied and first elucidated ncRNAs.

miRNAs and ovarian development. Dicer1 is an important RNase III enzyme that processes pre-miRNA into the shorter miRNA duplex (49). Mice with conditional knockout of Dicer exhibited increased primordial follicle pool endowment, increased degeneration of follicles and decreased ovulation rates (50). Functional studies using inhibition of miRNA biogenesis have demonstated the occurrence of developmental arrest and female infertility in various species. Otsuka et al (51) reported that miRNAs were associated with the secretion of progesterone by disturbing the function of ovarian corpus. Furthermore, Hossain et al (52) suggested that miRNAs were involved in the regulation of steroid hormone receptors in ovarian follicle growth.

piRNAs and ovarian development. piRNAs have been described to be present in ovarian follicle cells (53-56). piRNAs may suppress transposons in the ovarian somatic cells and inhibit transposable element to transfer into the female germline in Drosophila (53-55).

IncRNAs and ovarian development. In multicellular organisms, lncRNAs participated in cell differentiation and individual development as promoters or inhibitors (56). In germ cell development, lncRNAs regulate the expression of specific genes and serve key roles in the complex epigenetic process.

siRNAs and ovarian development. The mouse oocyte pseudogenegene siRNA system has been observed to preferentially target genes that are involved in microtubule dynamics (40). 
Table I. Classification of ncRNAs.

\begin{tabular}{|c|c|c|c|c|c|c|}
\hline Author, year & Name & Size & Location & Function & Illustrative example & Refs. \\
\hline $\begin{array}{l}\text { Mohr et al, 2015; } \\
\text { Sirotkin et al, } 2010 ; \\
\text { Jiang et al, } 2015\end{array}$ & miRNA & $18-24$ bp & $\begin{array}{l}\text { Encoded at } \\
\text { widespread } \\
\text { locations }\end{array}$ & $\begin{array}{l}\text { Targeting of mRNA } \\
\text { and shaping the } \\
\text { proteome of the cell }\end{array}$ & $\begin{array}{l}\mathrm{miR}-15 / 16 \text { miR-124a } \\
\mathrm{miR}-34 \mathrm{~b} / \mathrm{c} \mathrm{miR}-200\end{array}$ & $26-28$ \\
\hline $\begin{array}{l}\text { Thomson et al, 2009; } \\
\text { Aravin et al, 2007; } \\
\text { Aravin et al, 2007; } \\
\text { Brennecke et al, } 2007\end{array}$ & piRNA & $24-32 \mathrm{bp}$ & $\begin{array}{l}\text { Clusters, } \\
\text { intragenic }\end{array}$ & $\begin{array}{l}\text { Transposon repression, } \\
\text { DNA methylation }\end{array}$ & $\begin{array}{l}\text { piRNAs targeting } \\
\text { RASGRF1 and LINE1 } \\
\text { and IAP elements }\end{array}$ & $29-32$ \\
\hline $\begin{array}{l}\text { Kiss-László et al, 1996; } \\
\text { Ni et al, 1997; } \\
\text { King et al, } 2003\end{array}$ & snoRNA & $60-300 \mathrm{bp}$ & Intronic & $\begin{array}{l}\text { Ribosomal RNA } \\
\text { modifications }\end{array}$ & U50, SNORD & $35-37$ \\
\hline $\begin{array}{l}\text { Rinn et al, 2012; } \\
\text { Flynn et al, 2014; } \\
\text { Derrien } \text { et al, 2012 }\end{array}$ & $\operatorname{lncRNA}$ & $>200 \mathrm{bp}$ & Nucleus & DNA modifications & XIST, H19 & $8,41,43$ \\
\hline $\begin{array}{l}\text { Carthew et al, 2009; } \\
\text { Tam et al, } 2008\end{array}$ & siRNA & $20-30 \mathrm{bp}$ & Cytoplasm & mRNA silencing & & 38,40 \\
\hline
\end{tabular}

ncRNAs, non-coding RNAs; miRNA, microRNA; piRNA, PIWI-interacting RNA; snoRNA, small nucleolar RNA; lncRNA, long non-coding RNA.

\section{5. ncRNAs and ovarian tumorigenesis}

miRNAs and ovarian tumorigenesis. miRNAs serve important roles in tumorigenesis by acting as oncogenes or tumor suppressor genes (57-59). The members of the let-7 family of miRNAs were observed to be lost in ovarian cancer (59). Calin et al (60) reported that miRNAs were frequently located in fragile regions of the chromosomes associated with the development of ovarian carcinomas.

lncRNAs and ovarian tumorigenesis. Steroid receptor RNA activator (SRA) was initially characterized as an lncRNA by Lanz et al in 1999 (61). SRAs were strongly upregulated in ovarian tumors $(62,63)$, suggesting their potential role in ovary tumorigenesis. H19 acted as a type of lncRNA whose methylation imprinting was reported to be associated with the development of human benign ovarian teratomas (64). Yiya was identified as a $1.9 \mathrm{~kb}$ long ncRNA gene located $69 \mathrm{~kb}$ upstream of the transcription factor prospero-related homeobox 1 (65).

piRNAs and ovarian tumorigenesis. piRNAs have been reported to be involved in ovary tumorigenesis (21), although their specific function in tumorigenesis remains unclear. PIWI proteins have also been implicated in cancer development. For example, PIWIL2 was overexpressed in ovary tumors and inhibited apoptosis through the activation of the signal transducer and activator of transcription 3/Bcl-XL pathway (65).

snoRNAs and ovarian tumorigenesis. The potential role of snoRNAs in types of cancer, including non small cell lung cancer and breast cancer, has been reported previously (67-69), however the role of snoRNAs in the development of ovarian tumors remains unclear.

\section{6. ncRNAs and other ovarian diseases}

miRNAs and PCOS. Previous studies investigated the role of miRNAs in PCOS. Sang et al (20) identified seven differentially expressed miRNAs (miR-132, -320, -24, -520c-3p, -193b, -483-5p and -222) in patients with PCOS compared with healthy women. Subsequently, several groups identified differentially expressed miRNAs in rat PCOS models, including miR-9, -18b, -513-3p, -508-3p, -127-3p, -509-5p, -509-3p and $-93(70-72)$. The potential target genes were observed to have significantly decreased expression in the PCOS group, and included interleukin 8, synaptogamin 1 and insulin receptor substrate 2 , which were associated with the PCOS phenotype (70).

lncRNAs and PCOS. Mice lacking the progesterone receptor exhibited pleiotropic reproductive abnormalities (73). In the letrozole-induced rat PCOS model, Zurvarra et al (74) observed increased expression levels of androgen receptor and decreased expression of the estrogen and progesterone receptors. These data indicate that steroid receptors serve important roles in the etiology of PCOS. Furthermore, several studies demonstrated that IncRNA SRA was capable of promoting the activity of these steroid receptors $(75,76)$. Further studies are necessary to confirm the association between lncRNA SRA and PCOS.

miRNAs and POF. To understand the molecular mechanism of POF, several studies analyzed miRNAs and their target mRNAs $(22,77)$. Profiling of differentially expressed miRNAs in POF provided novel insight into the molecular events in POF development, with the upregulation of miR-151 and miR-672 targeting expression of TNFSF10 and FNDC1, which had been demonstrated to positively regulate cell apoptosis (77). 
Table II. Summary of ncRNAs involved in ovarian diseases.

\begin{tabular}{|c|c|c|c|c|c|}
\hline Author, year & ncRNAs & Diseases & Possible role or mechanism & Illustrative example & Refs. \\
\hline $\begin{array}{l}\text { Yang et al, 2012; } \\
\text { Kuang et al, } 2014\end{array}$ & miRNA & POF & $\begin{array}{l}\text { Downregulation of } \\
\text { phospholipase } A_{2}\end{array}$ & miR-29a, miR-144 & 22,77 \\
\hline $\begin{array}{l}\text { Sang et al, 2013; } \\
\text { Roth et al, 2014; } \\
\text { Liu et al, 2015; } \\
\text { Lin et al, } 2015\end{array}$ & miRNA & PCOS & $\begin{array}{l}\text { Regulation of steroidogenesis, } \\
\text { insulin regulation, inflammation, } \\
\text { lipid metabolism and oocyte } \\
\text { maturation }\end{array}$ & $\begin{array}{l}\text { miR-132, miR-320, } \\
\text { miR-32, miR-34c, } \\
\text { miR-135a, miR-9, } \\
\text { miR-92a, miR-92b }\end{array}$ & $20,70-72$ \\
\hline $\begin{array}{l}\text { Esquela-Kerscher } \\
\text { et al, 2006; } \\
\text { Hammond et al, 2007; } \\
\text { Croce et al, 2009; } \\
\text { Calin et al, } 2004\end{array}$ & miRNA & Cancer & $\begin{array}{l}\text { Inhibition of the expression of } \\
\text { cancer-associated genes, located at } \\
\text { fragile sites involved in cancer }\end{array}$ & let-7 & $57-60$ \\
\hline $\begin{array}{l}\text { Zhao et al, 2004; } \\
\text { Takayama et al, } 2011\end{array}$ & $\operatorname{lncRNA}$ & PCOS & $\begin{array}{l}\text { Promotion of the activity of steroid } \\
\text { receptors, enhancement of the } \\
\text { expression of neighboring } \\
\text { protein-coding genes }\end{array}$ & $\begin{array}{l}\text { XLOC_011402, } \\
\text { ENST00000454271 }\end{array}$ & 76,77 \\
\hline $\begin{array}{l}\text { Cooper et al, 2009; } \\
\text { Lanz et al, 2003; } \\
\text { Miura et al, 1999; } \\
\text { Yang et al, } 2012\end{array}$ & lncRNA & Cancer & $\begin{array}{l}\text { Methylation imprinting, promotion } \\
\text { of the cell cycle progression, } \\
\text { modification of prospero-related } \\
\text { homeobox } 1 \text { promoter }\end{array}$ & H19, Yiya & $62-65$ \\
\hline $\begin{array}{l}\text { Yan et al, 2011; } \\
\text { Lee et al, } 2006\end{array}$ & piRNA & Cancer & Inhibition of apoptosis & PIWI12 & 21,66 \\
\hline
\end{tabular}

ncRNAs, non-coding RNAs; miRNA, microRNA; lncRNA, long non-coding RNA; piRNA, PIWI-interacting RNA.

\section{Significance of ncRNAs in the diagnosis of ovarian diseases}

At present, it is not possible to elucidate whether altered ncRNA expression profiles are associated with the occurrence of ovarian diseases. However, miRNAs have been isolated from the blood, saliva, urine, feces, follicular fluid and other body fluids, and secreted miRNAs remain stable in body fluids, thus may serve as biomarkers for associated diseases (78). Several serum miRNAs (miR-222, miR-29a and let-7) have been suggested to act as novel non-invasive biomarkers for ovarian diseases $(59,77,79)$.

The technological development in the field, particularly bead-based flow cytometry, single molecule detection and massively parallel sequencing coupled with the mirage approach, may aid in the development of automated and high-speed ncRNAs profiling in the near future.

\section{Conclusion and perspective}

ncRNAs are highly abundant in living organisms and serve important roles in numerous biological processes. Therefore, there has been an increasing requirement to investigate the entire ncRNAomes and their biological function in further detail. In addition, aberrant ncRNA expression profiles are considered to be associated with the pathogenesis of ovarian diseases (Table II). To better understand the role of ncRNAs in ovarian diseases, future studies should focus on the molecular

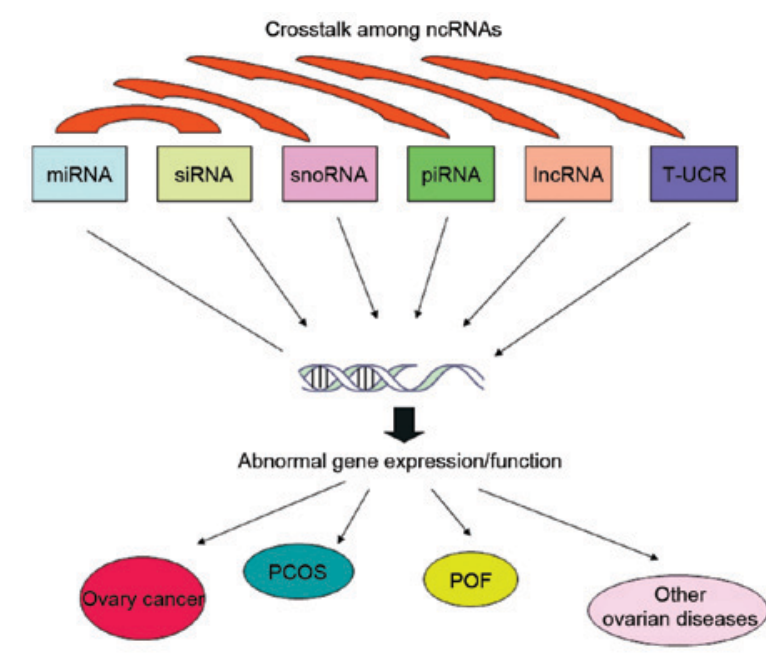

Figure 1. The ncRNAs crosstalk and form an ncRNA regulatory network to modulate gene expression and function via genetic and epigenetic mechanisms. The abnormal gene expression and function then leads to a variety of ovarian diseases including ovarian cancer, PCOS, and POF. ncRNAs, non-coding RNAs; PCOS, polycystic ovary syndrome; POF, premature ovarian failure; siRNA, small interfering RNA; snoRNA, small nucleolar RNA; piRNA, PIWI-interacting RNA; lncRNA, long non-coding RNA; T-UCR, transcribed ultraconserved region.

mechanisms by which abnormal expression of ncRNAs contributes to ovarian diseases, particularly the identification of the ncRNA regulation network and the interaction between 
ncRNAs and DNAs (Fig. 1). These investigations will aid in the identification of ncRNAs as novel diagnostic markers and therapeutic targets for ovarian diseases.

\section{Acknowledgements}

The current study was supported by the Pharmaceutical Industry Development Fund of Jiin Province (grant no. 20150311035YY).

\section{References}

1. Lee TI and Young RA: Transcriptional regulation and its misregulation in disease. Cell 152: 1237-1251, 2013.

2. Lawrence MS, Stojanov P, Mermel CH, Robinson JT, Garraway LA, Golub TR, Meyerson M, Gabriel SB, Lander ES and Getz G: Discovery and saturation analysis of cancer genes across 21 tumour types. Nature 505: 495-501, 2014.

3. MacLellan WR, Wang Y and Lusis AJ: Systems-based approaches to cardiovascular disease. Nat Rev Cardiol 9: 172-184, 2012.

4. Bai B, Hales CM, Chen PC, Gozal Y, Dammer EB, Fritz JJ, Wang X, Xia Q, Duong DM, Street C, et al: U1 small nuclear ribonucleoprotein complex and RNA splicing alterations in Alzheimer's disease. Proc Natl Acad Sci USA 110: 16562-16567, 2013.

5. Yang F, Yi F, Zheng Z, Ling Z, Ding J, Guo J, Mao W, Wang X, Ding X, Wang X, et al: Characterization of a carcinogenesis-associated long non-coding RNA. RNA Biol 9: 110-116, 2012.

6. ENCODE Project Consortium: An integrated encyclopedia of DNA elements in the human genome. Nature 489: 57-74, 2012.

7. Esteller M: Non-coding RNAs in human disease. Nat Rev Genet 12: 861-874, 2011.

8. Flynn RA and Chang HY: Long noncoding RNAs in cell-fate programming and reprogramming. Cell Stem Cell 14: 752-761, 2014.

9. Kung JT, Colognori D and Lee JT: Long noncoding RNAs: Past, present, and future. Genetics 193: 651-669, 2013.

10. Bachellerie JP, Cavaillé J and Hüttenhofer A: The expanding snoRNA world. Biochimie 84: 775-790, 2002.

11. van Stijn T and Galloway S: A BamHI polymorphism at the ovine inactive X-specific transcript locus (XIST). Anim Genet 26 279-280, 1995.

12. Brockdorff N, Ashworth A, Kay GF, McCabe VM, Norris DP, Cooper PJ, Swift S and Rastan S: The product of the mouse Xist gene is a $15 \mathrm{~kb}$ inactive $\mathrm{X}$-specific transcript containing no conserved ORF and located in the nucleus. Cell 71: 515-526, 1992.

13. Rinn JL, Kertesz M, Wang JK, Squazzo SL, Xu X, Brugmann SA, Goodnough LH, Helms JA, Farnham PJ, Segal E and Chang HY: Functional demarcation of active and silent chromatin domains in human HOX loci by noncoding RNAs. Cell 129: 1311-1323, 2007.

14. Dehwah MA, Xu A and Huang Q: MicroRNAs and type 2 diabetes/obesity. J Genet Genomics 39: 11-18, 2012.

15. Medina PP, Nolde $M$ and Slack FJ: OncomiR addiction in an in vivo model of microRNA-21-induced pre-B-cell lymphoma. Nature 467: 86-90, 2010

16. Zhao JJ, Lin J, Yang H, Kong W, He L, Ma X, Coppola D and Cheng JQ: MicroRNA-221/222 negatively regulates estrogen receptor alpha and is associated with tamoxifen resistance in breast cancer. J Biol Chem 283: 31079-31086, 2008.

17. Herrera-Esparza R, Kruse L, von Essen M, Campos L, Barbosa O, Bollain JJ, Badillo I and Avalos-Díaz E: U3 snoRNP associates with fibrillarin a component of the scleroderma clumpy nucleolar domain. Arch Dermatol Res 294: 310-317, 2002.

18. Yang JM, Hildebromdt B, Luderschmidt C and Pollard KM: Human scleroderma sera contain autoantibodies to protein components specific to the U3 small nucleolar RNP complex. Arthritis Rheum 48: 210-217, 2003.

19. Nicoloso MS, Spizzo R, Shimizu M, Rossi S and Calin GA: MicroRNAs-the micro steering wheel of tumour metastases. Nature Rev Cancer 9: 293-302, 2009.

20. Sang Q, Yao Z, Wang H, Feng R, Wang H, Zhao X, Xing Q, Jin L, $\mathrm{He} \mathrm{L}, \mathrm{Wu} \mathrm{L}$ and Wang L: Identification of microRNAs in human follicular fluid: Characterization of microRNAs that govern steroidogenesis in vitro and are associated with polycystic ovary syndrome in vivo. J Clin Endocrinol Metab 98: 3068-3079, 2013.
21. Yan Z, Hu HY, Jiang X, Maierhofer V, Neb E, He L, Hu Y, Hu H, Li N, Chen W and Khaitovich P: Widespread expression of piRNA-like molecules in somatic tissues. Nucleic Acids Res 39: 6596-6607, 2011.

22. Yang X, Zhou Y, Peng S, Wu L, Lin HY, Wang S and Wang H: Differentially expressed plasma microRNAs in premature ovarian failure patients and the potential regulatory function of mir-23a in granulosa cell apoptosis. Reproduction 144: 235-244, 2012.

23. Ohno S: So much 'junk' DNA in our genome. Brookhaven Symp Biol 23: 366-370, 1972.

24. Zhang R, Zhang L and Yu W: Genome-wide expression of non-coding RNA and global chromatin modification. Acta Biochim Biophys Sin (Shanghai) 44: 40-47, 2012.

25. Hertel J, de Jong D, Marz M, Rose D, Tafer H, Tanzer A, Schierwater B and Stadler PF: Non-coding RNA annotation of the genome of Trichoplax adhaerens. Nucleic Acids Res 37: 1602-1615, 2009.

26. Mohr AM and Mott JL: Overview of MicroRNA biology. Semin Liver Dis 35: 3-11, 2015.

27. Sirotkin AV, Lauková M, Ovcharenko D, Brenaut P and Mlyncek M: Identification of microRNAs controlling human ovarian cell proliferation and apoptosis. J Cell Physiol 223: 49-56, 2010.

28. Jiang L, Huang J, Li L, Chen Y, Chen X, Zhao X and Yang D: MicroRNA-93 promotes ovarian granulosa cells proliferation through targeting CDKN1A in polycystic ovarian syndrome. J Clin Endocrinol Metab 100: E729-E738, 2015.

29. Thomson T and Lin H: The biogenesis and function of PIWI proteins and piRNAs: Progress and prospect. Annu Rev Cell Dev Biol 25: 355-376, 2009.

30. Aravin AA, Hannon GJ and Brennecke J: The Piwi-piRNA pathway provides an adaptive defense in the transposon arms race. Science 318: 761-764, 2007.

31. Aravin AA, Sachidanandam R, Girard A, Fejes-Toth K and Hannon GJ: Developmentally regulated piRNA clusters implicate MILI in transposon control. Science 316: 744-747, 2007.

32. Brennecke J, Aravin AA, Stark A, Dus M, Kellis M, Sachidanandam R and Hannon GJ: Discrete small RNA-generating loci as master regulators of transposon activity in Drosophila. Cell 128: 1089-1103, 2007.

33. Gunawardane LS, Saito K, Nishida KM, Miyoshi K, Kawamura Y, Nagami T, Siomi H and Siomi MC: A slicer-mediated mechanism for repeat-associated siRNA 5' end formation in Drosophila. Science 315: 1587-1590, 2007.

34. Pal-Bhadra M, Leibovitch BA, Gandhi SG, Chikka MR, Bhadra U, Birchler JA and Elgin SC: Heterochromatic silencing and HP1 localization in Drosophila are dependent on the RNAi machinery. Science 303: 669-672, 2004.

35. Kiss-László Z, Henry Y, Bachellerie JP, Caizergues-Ferrer M and Kiss T: Site-specific ribose methylation of preribosomal RNA: A novel function for small nucleolar RNAs. Cell 85: 1077-1088, 1996.

36. Ni J, Tien AL and Fournier MJ: Small nucleolar RNAs direct site-specific synthesis of pseudouridine in ribosomal RNA. Cell 89: 565-573, 1997.

37. King TH, Liu B, McCully RR and Fournier MJ: Ribosome structure and activity are altered in cells lacking snoRNPs that form pseudouridines in the peptidyl transferase center. Mol Cell 11: 425-435, 2003.

38. Carthew RW and Sontheimer EJ: Origins and mechanisms of miRNAs and siRNAs. Cell 136: 642-655, 2009.

39. Diederichs $S$ and Haber DA: Dual role for argonautes in microRNA processing and posttranscriptional regulation of microRNA expression. Cell 131: 1097-1108, 2007.

40. Tam OH, Aravin AA, Stein P, Girard A, Murchison EP, Cheloufi S, Hodges E, Anger M, Sachidanandam R, Schultz RM and Hannon GJ: Pseudogene-derived small interfering RNAs regulate gene expression in mouse oocytes. Nature 453: 534-538, 2008

41. Rinn JL and Chang HY: Genome regulation by long noncoding RNAs. Annu Rev Biochem 81: 145-166, 2012.

42. Guttman M, Amit I, Garber M, French C, Lin MF, Feldser D, Huarte M, Zuk O, Carey BW, Cassady JP, et al: Chromatin signature reveals over a thousand highly conserved large non-coding RNAs in mammals. Nature 458: 223-227, 2009.

43. Derrien T, Johnson R, Bussotti G, Tanzer A, Djebali S, Tilgner H, Guernec G, Martin D, Merkel A, Knowles DG, et al: The GENCODE v7 catalog of human long noncoding RNAs: Analysis of their gene structure, evolution, and expression. Genome Res 22: 1775-1789, 2012.

44. Wang KC and Chang HY: Molecular mechanisms of long noncoding RNAs. Mol Cell 43: 904-914, 2011. 
45. Brannan CI, Dees EC, Ingram RS and Tilghman SM: The product of the H19 gene may function as an RNA. Mol Cell Biol 10: 28-36, 1990.

46. Okamura K and Lai EC: Endogenous small interfering RNAs in animals. Nat Rev Mol Cell Biol 9: 673-678, 2008.

47. Ørom UA, Derrien T, Guigo R and Shiekhattar R: Long noncoding RNAs as enhancers of gene expression. Cold Spring Harb Symp Quant Biol 75: 325-331, 2010.

48. Feuerhahn S, Iglesias N, Panza A, Porro A and Lingner J: TERRA biogenesis, turnover and implications for function. FEBS Lett 584: 3812-3818, 2010.

49. Kanellopoulou C, Muljo SA, Kung AL, Ganesan S, Drapkin R, Jenuwein T, Livingston DM and Rajewsky K: Dicer-deficient mouse embryonic stem cells are defective in differentiation and centromeric silencing. Genes Dev 19: 489-501, 2005.

50. Lei L, Jin S, Gonzalez G, Behringer RR and Woodruff TK: The regulatory role of Dicer in folliculogenesis in mice. Mol Cell Endocrinol 315: 63-73, 2010.

51. Otsuka M, Zheng M, Hayashi M, Lee JD, Yoshino O, Lin S and Han J: Impaired microRNA processing causes corpus luteum insufficiency and infertility in mice. J Clin Invest 118: 1944-1954, 2008.

52. Hossain MM, Cao M, Wang Q, Kim JY, Schellander K, Tesfaye D and Tsang BK: Altered expression of miRNAs in a dihydrotestosterone-induced rat PCOS model. J Ovarian Res 6: 36, 2013

53. Malone CD, Brennecke J, Dus M, Stark A, McCombie WR, Sachidanandam R and Hannon GJ: Specialized piRNA pathways act in germline and somatic tissues of the Drosophila ovary. Cell 137: 522-535, 2009.

54. Li C, Vagin VV, Lee S, Xu J, Ma S, Xi H, Seitz H, Horwich MD, Syrzycka M, Honda BM, et al: Collapse of germline piRNAs in the absence of Argonaute3 reveals somatic piRNAs in flies. Cell 137: 509-521, 2009.

55. Saito K, Inagaki S, Mituyama T, Kawamura Y, Ono Y, Sakota E, Kotani H, Asai K, Siomi H and Siomi MC: A regulatory circuit for piwi by the large Maf gene traffic jam in Drosophila. Nature 461: 1296-1299, 2009.

56. Sasaki $\mathrm{H}$ and Matsui Y: Epigenetic events in mammalian germ-cell development: Reprogramming and beyond. Nat Rev Genet 9: 129-140, 2008

57. Esquela-Kerscher A and Slack FJ: OncomiRs-microRNAs with a role in cancer. Nat Rev Cancer 6: 259-269, 2006.

58. Hammond SM: MicroRNAs as tumor suppressors. Nat Genet 39: 582-583, 2007.

59. Croce CM: Causes and consequences of microRNA dysregulation in cancer. Nat Rev Genet 10: 704-714, 2009.

60. Calin GA, Sevignani C, Dumitru CD, Hyslop T, Noch E, Yendamuri S, Shimizu M, Rattan S, Bullrich F, Negrini M and Croce CM: Human microRNA genes are frequently located at fragile sites and genomic regions involved in cancers. Proc Natl Acad Sci USA 101: 2999-3004, 2004

61. Lanz RB, McKenna NJ, Onate SA, Albrecht U, Wong J, Tsai SY, Tsai MJ and O'Malley BW: A steroid receptor coactivator, SRA, functions as an RNA and is present in an SRC-1 complex. Cell 97: 17-27, 1999

62. Cooper C, Guo J, Yan Y, Chooniedass-Kothari S, Hube F, Hamedani MK, Murphy LC, Myal Y and Leygue E: Increasing the relative expression of endogenous non-coding Steroid Receptor RNA Activator (SRA) in human breast cancer cells using modified oligonucleotides. Nucleic Acids Res 37: 4518-4531, 2009.

63. Lanz RB, Chua SS, Barron N, Söder BM, DeMayo F and O'Malley BW: Steroid receptor RNA activator stimulates proliferation as well as apoptosis in vivo. Mol Cell Biol 23: 7163-7176, 2003.
64. Miura K, Obama M, Yun K, Masuzaki H, Ikeda Y, Yoshimura S, Akashi T, Niikawa N, Ishimaru T and Jinno Y: Methylation imprinting of H19 and SNRPN genes in human benign ovarian teratomas. Am J Hum Genet 65: 1359-1367, 1999.

65. Yang F, Yi F, Zheng Z, Ling Z, Ding J, Guo J, Mao W, Wang X, Wang X, Ding X, et al: Characterization of a carcinogenesis-associated long non-coding RNA. RNA Biol 9: 110-116, 2012.

66. Lee JH, Schütte D, Wulf G, Füzesi L, Radzun HJ, Schweyer S, Engel W and Nayernia K: Stem-cell protein Piwil2 is widely expressed in tumors and inhibits apoptosis through activation of Stat3/Bcl-XL pathway. Hum Mol Genet 15: 201-211, 2006.

67. Chang LS, Lin SY, Lieu AS and Wu TL: Differential expression of human 5S snoRNA genes. Biochem Biophys Res Commun 299: 196-200, 2002

68. Liao J, Yu L, Mei Y, Guarnera M, Shen J, Li R, Liu Z and Jiang F: Small nucleolar RNA signatures as biomarkers for non-small-cell lung cancer. Mol Cancer 9: 198, 2010.

69. Dong XY, Guo P, Boyd J, Sun X, Li Q, Zhou W and Dong JT: Implication of snoRNA U50 in human breast cancer. J Genet Genomics 36: 447-454, 2009.

70. Roth LW, McCallie B, Alvero R, Schoolcraft WB, Minjarez D and Katz-Jaffe MG: Altered microRNA and gene expression in the follicular fluid of women with polycystic ovary syndrome. J Assist Reprod Genet 31: 355-362, 2014.

71. Liu S, Zhang X, Shi C, Lin J, Chen G, Wu B, Wu L, Shi H, Yuan Y, Zhou W, et al: Altered microRNAs expression profiling in cumulus cells from patients with polycystic ovary syndrome. J Transl Med 13: 238, 2015 .

72. Lin L, Du T, Huang J, Huang LL and Yang DZ: Identification of differentially expressed microRNAs in the ovary of polycystic ovary syndrome with hyperandrogenism and insulin resistance. Chin Med J (Enql) 128: 169-174, 2015.

73. Lydon JP, DeMayo FJ, Funk CR, Mani SK, Hughes AR, MontgomeryCA Jr, Shyamala G, Conneely OM and O'Malley BW: Mice lacking progesterone receptor exhibit pleiotropic reproductive abnormalities. Genes Dev 9: 2266-2278, 1995.

74. Zurvarra FM, Salvetti NR, Mason JI, Velazquez MM, Alfaro NS and Ortega HH: Disruption in the expression and immunolocalisation of steroid receptors and steroidogenic enzymes in letrozole-induced polycystic ovaries in rat. Reprod Fertil Dev 21: 827-839, 2009.

75. Zhao X, Patton JR, Davis SL, Florence B, Ames SJ and Spanjaard RA: Regulation of nuclear receptor activity by a pseudouridine synthase through posttranscriptional modification of steroid receptor RNA activator. Mol Cell 15: 549-558, 2004.

76. Takayama K, Tsutsumi S, Katayama S, Okayama T, Horie-Inoue K, Ikeda K, Urano T, Kawazu C, Hasegawa A, Ikeo $\mathrm{K}$, et al: Integration of cap analysis of gene expression and chromatin immunoprecipitation analysis on array reveals genome-wide androgen receptor signaling in prostate cancer cells. Oncogene 30: 619-630, 2011.

77. Kuang H, Han D, Xie J, Yan Y, Li J and Ge P: Profiling of differentially expressed microRNAs in premature ovarian failure in an animal model. Gynecol Endocrinol 30: 57-61, 2014.

78. Chen X, Ba Y, Ma L, Cai X, Yin Y, Wang K, Guo J, Zhang Y, Chen J, Guo X, et al: Characterization of microRNAs in serum: A novel class of biomarkers for diagnosis of cancer and other diseases. Cell Res 18: 997-1006, 2008

79. Long W, Zhao C, Ji C, Ding H, Cui Y, Guo X, Shen R and Liu J: Characterization of serum microRNAs profile of PCOS and identification of novel non-invasive biomarkers. Cell Physiol Biochem 33: 1304-1315, 2014. 